\title{
Chemical Study and Biological Activity Evaluation of Two Azorean Macroalgae: Ulva rigida and Gelidium microdon
}

\author{
Madalena Silva ${ }^{1}$, Luís M. M. Vieira ${ }^{2}$, Ana Paula Almeida ${ }^{3,4}$, Artur M. S. Silva ${ }^{5}$, Ana M. L. Seca ${ }^{5,6}$, M. Carmo Barreto ${ }^{6}$ Ana I. Neto ${ }^{1,7}$, Madalena \\ Pedro $^{4,8}$, Eugénia Pinto ${ }^{4,9}$ and Anake Kijjoa ${ }^{1,2 *}$
}

${ }^{1}$ CIIMAR - Centro Interdisciplinar de Investigação Marinha e Ambiental, Universidade do Porto, Porto, Portugal

${ }^{2}$ ICBAS - Departamento de Química, Instituto de Ciências Biomédicas de Abel Salazar, Universidade do Porto, Porto, Portugal

${ }^{3}$ Mestrado em Ciências Ambientais, Universidade Severino Sombra (USS), Rio de Janeiro, Brazil

${ }^{4}$ CEQUIMED - Centro de Química Medicinal da Universidade do Porto, Porto, Portugal

${ }^{5}$ Departamento de Química \& QOPNA, Universidade de Aveiro, Aveiro, Portugal

${ }^{6}$ Departamento de Ciências Tecnológicas e Desenvolvimento, Universidade dos Açores, Ponta Delgada, Portugal

${ }^{7}$ CIRN \& Departamento de Biologia, Universidade dos Açores, Ponta Delgada, Portugal

${ }^{8}$ CESPU - Cooperativa de Ensino Superior, Politécnico e Universitário, Gandra, Portugal

${ }^{9}$ Laboratório de Microbiologia, Departamento de Ciências Biológicas, Faculdade de Farmácia da Universidade do Porto, Porto, Portugal

\begin{abstract}
The green macroalga Ulva rigida C. Agardh (Chlorophyta) and the red macroalga Gelidium microdon Kützing (Rhodophyta), collected from the Azorean archipelago, were investigated for their secondary metabolites and their in vitro growth inhibitory effect on three human tumor cell lines: MCF-7 (breast adenocarcinoma), NCl-H460 (non-small cell lung cancer) and A375-C5 (melanoma), as well as for their antifungal and antibacterial activities. The methanol extract

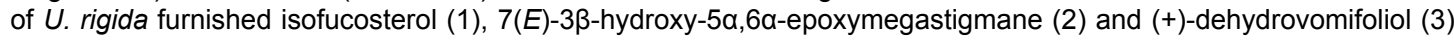
while the methanol extract of $G$. microdon yielded cholesterol (4) and lumichrome (5). The crude extracts of both macroalgae were found to be moderately active against the three cell lines whereas compound 1 showed a weak effect and compound 2 was inactive. The crude extracts of the two macroalgae were found to be moderately active against some fungi and bacteria while compounds 1 and 2 were inactive against all microorganisms tested.
\end{abstract}

Keywords: Azores; Macroalgae; Ulva rigida; Gelidium microdon; Isofucosterol; $7(E)$-3 $\beta$-hydroxy-5a,6a-epoxymegastigmane; (+)-dehydrovomifoliol; Lumichrome; Antitumor; Antimicrobial

Abbreviations: $\mathrm{MeOH}$ - Methanol; $\mathrm{Me}_{2} \mathrm{CO}$ - Acetone; $\delta$ Chemical Shift in ppm; DMSO - Dimethyl Sulphoxide; HR-ESIMS - High Resolution Electrospray Ionization Mass Spectrometry; SRB Sulforhodamine B; MIC - Minimal Inhibitory Concentration; MLC Minimal Lethal Concentration

\section{Introduction}

The marine environment is an exceptional reservoir of bioactive compounds, many of which exhibit structural/chemical features not found in terrestrial natural products. This is easily understood since the Ocean, which covers almost $71 \%$ of the Earth's surface and represents a uniqueness of the physical and chemical conditions, is considered as a very promising source of Natural Products covering a wide range of bioactivities [1-6]. Therefore, marine Natural Products continue to play a major role in drug discovery.

Since the Azorean archipelago is located in the warm temperate region of the North East Atlantic, approximately $1200 \mathrm{~km}$ from Europe, the marine fauna and flora of this group of islands appear to be a mixture of species which can be found both in the Atlantic and the Mediterranean [7]. Marine macroalgae are abundant and structuring organisms of the coastal area of the entire Azores archipelago, some having a markedly seasonal pattern and others being present during the whole year in the Azorean coasts [8-10]. The geographical distribution of these macroalgae is related to the temperature regime of the region where they grow, reproduce, and survive. However, the diversity and abundance of these organisms depend on many other biological factors [11], leading to production of different secondary metabolites of the species from different geographical locations [12]. Macroalgae produce myriads of secondary metabolites which are synthesized at the end of the growth phase and/or due to metabolic alterations induced by environmental stress conditions [13]. These metabolites have been targets of the drug discovery program and some of these bioactive compounds such as sulfated polysaccharides, steroids and diterpenes have found their applications in the pharmaceutical industry $[14,15]$.

During our on-going project aiming at exploiting bioactive secondary metabolites from macroalgae of the Azorean archipelago for added-value products, we have conducted phytochemical studies of the green alga Ulva rigida C. Agardh and the red alga Gelidium microdon Kützing, and evaluation of the in vitro antitumor and antimicrobial activities of the crude extracts of these two macroalgae as well as their isolated metabolites. The main reasons for selection of these two species were based on the fact that Ulva and Gelidium species are well-recognized sources of industrially important biopolymers and the organic crude extracts of these two species had been previously found to exhibit a promising in vitro cytotoxicity on cancer cell lines and antioxidant activity [16]. Furthermore, they are abundant in the Azorean intertidal areas [8,17]. Although both species are locally abundant and dominant at the Azorean intertidal bedrock areas, $U$. rigida is common and abundant at mid and low shore levels whereas G. microdon is extremely abundant at mid shore level. Consequently,

*Corresponding author: Prof. Anake Kijjoa, ICBAS - Instituto de Ciências Biomédicas de Abel Salazar, Universidade do Porto, Rua de Jorge Viterbo Ferreira, 228, 4050-313, Porto, Portugal, Tel: +351-220428331; Fax :+351-220428090; E-mail: ankijjoa@icbas.up.pt

Received February 10, 2013; Accepted April 26, 2013; Published April 30, 2013

Citation: Silva M, Vieira LMM, Almeida AP, Silva AMS, Seca AML, et al. (2013) Chemical Study and Biological Activity Evaluation of Two Azorean Macroalgae: Ulva rigida and Gelidium microdon. Oceanography 1: 102. doi:10.4172/23322632.1000102

Copyright: $\odot 2013$ Silva M, et al. This is an open-access article distributed unde the terms of the Creative Commons Attribution License, which permits unrestricted use, distribution, and reproduction in any medium, provided the original author and source are credited. 
Citation: Silva M, Vieira LMM, Almeida AP, Silva AMS, Seca AML, et al. (2013) Chemical Study and Biological Activity Evaluation of Two Azorean Macroalgae: Ulva rigida and Gelidium microdon. Oceanography 1: 102. doi:10.4172/2332-2632.1000102

their abundance and easy access for collection can guarantee their quantity for further biotechnological exploitation in the future. Furthermore, as these two species are annual and intertidal, they do not present any significant variations of the concentrations of their secondary metabolites, which can be influenced by their age and depth of the collection site. Although both Ulva and Gelidium species have been extensively investigated as sources of biotechnologically relevant biopolymers, their secondary metabolites have never been fully exploited for value-added products. While Ulva species are an important source of ulvan, a natural sulfated polysaccharide which has been extensively investigated for development of novel drugs and functional foods [18], Gelidium species are one of the main sources of phycocolloids, such as agar [19,20]. Several types of secondary metabolites such as bromophenol [21-23], sesquiterpenes [24,25], and steroids $[23,26]$ have been previously reported from the macroalgae of the genus Ulva; however, there are only few reports on the chemical constituents of the genus Gelidium. While gelidene, a polyhalogenated monocyclic monoterpene, was isolated from G. sesquipedale [27], jasmonic acid was reported from G. latifolium [28].

Due to the pristine environment of the Azorean archipelago, we have elaborated the project aiming to exploit the potential of the macroalgae of this region. The collections of these two species were carried out in May and October in order to allow us to study their chemical compositions in different seasons, i.e. spring and autumn, as well as of two different reproductive stages. We now report the chemical study together with the antitumor and antimicrobial activities evaluation of the first collection (May 2011) of the green macroalga
$U$. rigida and the red macroalga G. microdon from S. Miguel Island which is considered to be one of the environmentally healthy habitats and rich in algal communities of the Azorean Sea. Examination of the methanol extract of $U$. rigida led to isolation of isofucosterol $(1), 7(E)$ $3 \beta$-hydroxy-5a,6a-epoxymegastigmane (2) and (+)-dehydrovomifoliol (3), while the methanol extract of G. microdon yielded cholesterol (4) and lumichrome (5) (Figure 1). The crude extracts of both

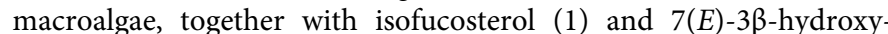
$5 a, 6 a$-epoxymegastigmane (2), were evaluated for their in vitro growth inhibition on three tumor cell lines: MCF-7, NCI-H460 and A375-C5, as well as for their antifungal and antibacterial activities.

\section{Material and Methods}

\section{General experimental procedures}

Melting points were determined on a Bock monoscope and are uncorrected. Optical rotations were determined on an ADP410 Polarimeter. ${ }^{1} \mathrm{H}$ and ${ }^{13} \mathrm{C}$ NMR spectra were recorded at ambient temperature on a Bruker Advance instrument operating at 300.13 and $75.4 \mathrm{MHz}$, respectively. High resolution mass spectra were measured with a Waters Xevo QToF mass spectrometer coupled to a Waters Aquity UPLC system. A Merck silica gel GF 254 was used for preparative TLC, and a Merck Si gel $60(0.2-0.5 \mathrm{~mm})$ was used for analytical chromatography.

\section{Biological material}

U. rigida and G. microdon were collected in May 2011 from the<smiles>C/C=C(/CC[C@H](C)C1CC[C@H]2[C@@H]3CC=C4C[C@@H](O)CC[C@]4(C)[C@]3(C)CC[C@]12C)C(C)C</smiles>

1

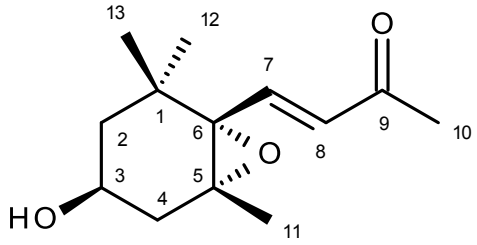<smiles>CC(=O)/C=C/[C@@]1(O)[C@@H](C)C=C(C)CC1(C)C</smiles>

3<smiles></smiles>

4<smiles>Cc1cc2nc3[nH]c(=O)[nH]c(=O)c3nc2cc1C</smiles>

5

Figure 1: Structures of isofucosterol (1), 7(E)-3ß-hydroxy-5a,6a-epoxymegastigmane (2) and (+)-dehydrovomifoliol (3), isolated from Ulva rigida and cholesterol (4) and lumichrome (5), isolated from Gelidium microdon. 
Citation: Silva M, Vieira LMM, Almeida AP, Silva AMS, Seca AML, et al. (2013) Chemical Study and Biological Activity Evaluation of Two Azorean Macroalgae: Ulva rigida and Gelidium microdon. Oceanography 1: 102. doi:10.4172/2332-2632.1000102

coast of S. Miguel island - Azores archipelago, and the samples of both macroalgae were deposited at the Department of Biology of University of Azores (Vouchers: SMG-11-49 and SMG-11-30, respectively).

\section{Extraction and isolation of the constituents}

Dried powdered material (U. rigida - $1472.5 \mathrm{~g}$ and G. microdon $1293.4 \mathrm{~g}$ ) was percolated with $\mathrm{MeOH}$, at room temperature until exhaustion. The resulting solutions were filtered with filter paper (Whatman no 1) and concentrated under reduced pressure to yield crude extracts of $U$. rigida (154.49 g) and G. microdon (151.91 g). Treatment of the crude methanol extracts to remove the chlorophylls [29], furnished $14.22 \mathrm{~g}$ of $U$. rigida and $4.74 \mathrm{~g}$ of G. microdon purified extracts.

$U$. rigida - The purified extract ( $14.22 \mathrm{~g})$ was chromatographed over a $0.2-0.5 \mathrm{~mm} \mathrm{Si} \mathrm{Gel} \mathrm{column}(180 \mathrm{~g})$ and eluted with mixtures of petroleum ether, $\mathrm{CHCl}_{3}$ and $\mathrm{Me}_{2} \mathrm{CO}$, wherein $250 \mathrm{ml}$ fractions were collected as follows: frs 1-2 (petroleum ether- $\mathrm{CHCl}_{3}, 9: 1$ ), frs 3-52 (petroleum ether/ $\mathrm{CHCl}_{3}, 4: 1$ ), frs 53-112 (petroleum ether- $\mathrm{CHCl}_{3}, 1: 1$ ), frs 113-126 (petroleum ether- $\left.\mathrm{CHCl}_{3}, 1: 4\right)$, frs $127-145\left(\mathrm{CHCl}_{3}\right)$, frs 146$167\left(\mathrm{CHCl}_{3}-\mathrm{Me}_{2} \mathrm{CO}, 9: 1\right)$, frs 168-211 $\left(\mathrm{CHCl}_{3}-\mathrm{Me}_{2} \mathrm{CO}, 4: 1\right)$, frs 212-243 $\left(\mathrm{CHCl}_{3}-\mathrm{Me}_{2} \mathrm{CO}, 1: 1\right)$, frs 244-289 $\left(\mathrm{CHCl}_{3}-\mathrm{Me}_{2} \mathrm{CO}, 1: 4\right)$, frs $290-303$ $\left(\mathrm{Me}_{2} \mathrm{CO}\right)$. Frs 30 and 31 were combined $(691.1 \mathrm{mg})$ and recrystallized in petroleum ether to give $32.0 \mathrm{mg}$ of compound 1 . Frs $93-106$ were combined $\left(121.9 \mathrm{mg}\right.$ ) and purified by TLC ( $\mathrm{Si} \mathrm{Gel,} \mathrm{CHCl}_{3}$-EtOAcpetroleum ether- $\left.\mathrm{HCO}_{2} \mathrm{H} ; 3: 1: 1: 0.01\right)$, to yield compound $2(10.8 \mathrm{mg})$ and a mixture $(4.6 \mathrm{mg})$ containing compound 3 as a major component.

G. microdon - The purified extract $(4.74 \mathrm{~g})$ was chromatographed over a $0.2-0.5 \mathrm{~mm} \mathrm{Si} \mathrm{Gel} \mathrm{column}(120 \mathrm{~g})$ and eluted with mixtures of petroleum ether, $\mathrm{CHCl}_{3}, \mathrm{Me}_{2} \mathrm{CO}$ and $\mathrm{MeOH}, 250 \mathrm{ml}$ fractions were collected as follows: frs 1-23 (petroleum ether- $\mathrm{CHCl}_{3}, 4: 1$ ), frs 24-73 (petroleum ether- $\mathrm{CHCl}_{3}, 3: 2$ ), frs 74-112 (petroleum ether- $\mathrm{CHCl}_{3}$, 1:4), frs 113-125 (petroleum ether- $\left.\mathrm{CHCl}_{3}, 1: 9\right)$, frs $126-142\left(\mathrm{CHCl}_{3}\right)$, frs 143-175 $\left(\mathrm{CHCl}_{3}-\mathrm{Me}_{2} \mathrm{CO}, 9: 1\right)$, frs 176-200 $\left(\mathrm{CHCl}_{3}-\mathrm{Me}_{2} \mathrm{CO}, 7: 3\right)$, frs 201-231 $\left(\mathrm{CHCl}_{3}-\mathrm{Me}_{2} \mathrm{CO}, 1: 1\right)$, frs 232-236 $\left(\mathrm{CHCl}_{3}-\mathrm{Me}_{2} \mathrm{CO}, 3: 7\right)$, frs 237-256 ( $\left.\mathrm{CHCl}_{3}-\mathrm{MeOH}, 9: 1\right)$, frs 257-267 ( $\left.\mathrm{CHCl}_{3}-\mathrm{MeOH}, 4: 1\right)$, frs 268$280\left(\mathrm{CHCl}_{3}-\mathrm{MeOH}, 1: 1\right)$, frs $281-294\left(\mathrm{CHCl}_{3}-\mathrm{MeOH}, 3: 7\right)$, frs $295-300$ $(\mathrm{MeOH})$. Frs 11-22 were combined $(665.4 \mathrm{mg})$ and purified by TLC ( $\mathrm{Si}$ gel, $\mathrm{CHCl}_{3}$-toluene- $\left.\mathrm{HCO}_{2} \mathrm{H}, 7: 3: 0.1\right)$ to give $66.9 \mathrm{mg}$ of cholesterol (4) [30]. Frs 81-100 were combined (127.6 mg) and recrystallized in $\mathrm{CHCl}_{3}$ to yield $2.7 \mathrm{mg}$ of lumichrome (5).

Isofucosterol (1): White crystals; mp. $129-131^{\circ} \mathrm{C} .[\alpha]_{D}^{25}=-36.2^{\circ}(c$ $\left.0.083 \mathrm{~g} \mathrm{~mL}^{-1}, \mathrm{CHCl}_{3}\right)$ Lit: $\mathrm{mp} 128-130^{\circ} \mathrm{C} .[\alpha]_{D}^{25}=-36.8^{\circ}\left(c 0.02 \mathrm{~g} \mathrm{~mL}^{-1}\right.$, $\left.\mathrm{CHCl}_{3}\right)[31] .{ }^{1} \mathrm{H}-\mathrm{NMR}\left(300 \mathrm{MHz}, \mathrm{CDCl}_{3}\right) \delta$ in ppm: $5.35 d d(J=1.7,4.4$ $\mathrm{Hz}, \mathrm{H}-6), 5.10 q(J=6.8 \mathrm{~Hz}, \mathrm{H}-28), 3.52$ dddd $(J=1.2,5.6,10.7,10.7 \mathrm{~Hz}$, $\mathrm{H}-3), 2.83 m$ (H-25), $2.29 m$ (H-4), 1.9-2.1 $m$ (H-7, H-8, H-12, H-23), 1.7-1.9 $m$ (H-1, H-2, H-16, H-23), 1.4-1.6 m (H-7, H-8, H-11, H-15, H-20, H-22), 0.9-1.3 $m$ (H-9, H-12, H-14, H-15, H-16, H-17, H-22), $1.59 d(J=6.8 \mathrm{~Hz}, \mathrm{H}-29), 1.01 s(\mathrm{H}-19), 0.95 d(J=6.6 \mathrm{~Hz}, \mathrm{H}-21), 0.98 d$ $(J=6.9 \mathrm{~Hz}, \mathrm{H}-26, \mathrm{H}-27), 0.68 s(\mathrm{H}-18) .{ }^{13} \mathrm{C}-\mathrm{NMR}\left(75 \mathrm{MHz}, \mathrm{CDCl}_{3}\right) \delta$ in ppm: $145.9 s$ (C-24), $140.7 s$ (C-5), $121.7 d$ (C-6), $116.4 d$ (C-28), 71.8 $d(\mathrm{C}-3), 56.7 d$ (C-14), $56.0 d$ (C-17), $50.1 d(\mathrm{C}-9), 42.3 s$ (C-13), $42.3 t$ (C-4), $39.8 t(\mathrm{C}-12), 37.2 t(\mathrm{C}-1), 36.5 s(\mathrm{C}-10), 36.1$ (C-20), 35.9 (C-22), $32.0 t$ (C-7), $31.9 d$ (C-8), $31.6 t$ (C-2), $28.6 d$ (C-25), $28.2 t$ (C-16), 27.9 $t$ (C-23), $24.3 t$ (C-15), $21.2 t(\mathrm{C}-11), 21.1 q(\mathrm{C}-26), 21.0 q$ (C-27), 19.4 $q(\mathrm{C}-19), 18.8 q(\mathrm{C}-21), 12.8 q(\mathrm{C}-29), 11.8 q(\mathrm{C}-18)$.

$7(E)-3 \beta$-Hydroxy-5a, 6a-epoxymegastigmane (2): Oil; $[\alpha]_{D}^{25}=-$ $38.5^{\circ}\left(c 0.026 \mathrm{~g} \mathrm{~mL}^{-1}, \mathrm{CHCl}_{3}\right)$ Lit: $[\alpha]_{D}^{25}=-43.7^{\circ}\left(c 0.39 \mathrm{~g} \mathrm{~mL}^{-1}, \mathrm{CH}_{2} \mathrm{Cl}_{2}\right)$ [32]. ${ }^{1} \mathrm{H}$ and ${ }^{13} \mathrm{C}$ NMR (Table 1).
(+)-Dehydrovomifoliol (3): White amorphous powder. ${ }^{1} \mathrm{H}$ and ${ }^{13} \mathrm{C}$ NMR (Table 2).

Cholesterol (4): White crystals; mp. $146-147^{\circ} \mathrm{C}$; ${ }^{1} \mathrm{H}$ NMR $(300$ $\left.\mathrm{MHz}, \mathrm{CDCl}_{3}\right) \delta 5.36 d(J=5.2 \mathrm{~Hz}, \mathrm{H}-5), 3.53 m(\mathrm{H}-3), 2.2-2.4 m(\mathrm{H}-4$ and $\mathrm{H}-13), 1.9-2.1 m(\mathrm{H}-7, \mathrm{H}-12) 1.4-1.6 m(\mathrm{H}-1$ and $\mathrm{H}-2), 1.02 s(\mathrm{H}-$ $19,3 \mathrm{H}), 0.92 d(J=6.5 \mathrm{~Hz}, \mathrm{H}-21,3 \mathrm{H}), 0.88 d(J=6.6 \mathrm{~Hz}, \mathrm{H}-27,3 \mathrm{H}), 0.87$ $d(J=6.6 \mathrm{~Hz}, \mathrm{H}-27,3 \mathrm{H}), 0.69 s(\mathrm{H}-18,3 \mathrm{H}) ;{ }^{13} \mathrm{C}-\mathrm{NMR}\left(75 \mathrm{MHz}, \mathrm{CDCl}_{3}\right)$ $\delta 140.7 s(\mathrm{C}-5), 121.7 d(\mathrm{C}-6), 71.8 d(\mathrm{C}-3), 56.8 d(\mathrm{C}-17), 56.1 s(\mathrm{C}-14)$, $50.1 d$ (C-9), $42.3 t$ (C-4 and C-13), $39.8 t(\mathrm{C}-12), 39.5 t(\mathrm{C}-24), 37.2 t$ (C-1), $36.5 s(\mathrm{C}-10), 36.2 t(\mathrm{C}-22), 35.8 d(\mathrm{C}-20), 31.9 t(\mathrm{C}-7), 31.9 t(\mathrm{C}-$ 8), $31.7 t(\mathrm{C}-2), 28.2 t$ (C-16), $28.0 d(\mathrm{C}-25) 24.3 t(\mathrm{C}-15), 23.8 t(\mathrm{C}-23)$, 22,8 $q$ (C-27), $22.6 q$ (C-26), $21.1 t(\mathrm{C}-11), 19.4 q(\mathrm{C}-19), 18.7 q(\mathrm{C}-21)$ $11.9 q(\mathrm{C}-18)$.

Lumichrome (5): Green amorphous powder. HR-ESIMS $\mathrm{m} / \mathrm{z}$ $243.0918[\mathrm{M}+\mathrm{H}]^{+}\left(\right.$calcd for $\left.\mathrm{C}_{12} \mathrm{H}_{11} \mathrm{~N}_{4} \mathrm{O}_{2}, 243.0882\right) ;{ }^{1} \mathrm{H}$ and ${ }^{13} \mathrm{C}$ NMR (Table 3).

\section{Growth inhibition of human tumor cell lines}

The effect of the extracts and of compounds 1 and 2 were evaluated for their capacity to inhibit in vitro growth of three human tumor cell lines: MCF-7 (breast adenocarcinoma), NCI-H460 (non-small cell lung cancer) and A375-C5 (melanoma), according to the procedure adopted by the National Cancer Institute (NCI) in the "In vitro Anticancer Drug Discovery Screen" that uses the protein-binding dye SRB to

\begin{tabular}{|c|c|c|c|c|}
\hline Position & $\delta_{\mathrm{C}}$, type & $\delta_{\mathrm{H}},(\mathrm{J}$ in $\mathrm{Hz})$ & $\mathrm{COSY}$ & $\mathrm{HMBC}$ \\
\hline 1 & $35.1, \mathrm{C}$ & & & \\
\hline $2 \alpha$ & $46.6, \mathrm{CH}_{2}$ & $1.64, \mathrm{dt}(12.9,1.8)$ & $\mathrm{H}-2 \beta$ & \\
\hline$\beta$ & & $1.26, \mathrm{dt}(12.9,10.4)$ & $\mathrm{H}-2 \alpha$ & \\
\hline 3 & $64.0, \mathrm{CH}$ & $3.90, \mathrm{~m}$ & & \\
\hline $4 \alpha$ & $40.5, \mathrm{CH}_{2}$ & $2.39, \mathrm{ddd}(14.5,5.1,1.7)$ & $\mathrm{H}-2 \beta$ & $\mathrm{C}-3,5,6$ \\
\hline$\beta$ & & $1.66, \mathrm{dd}(14.5,8.7)$ & $\mathrm{H}-2 \alpha$ & $\mathrm{C}-2,5$ \\
\hline 5 & $67.3, \mathrm{C}$ & & & \\
\hline 6 & $69.4, \mathrm{C}$ & & & \\
\hline 7 & $142.4, \mathrm{CH}$ & $7.03, \mathrm{~d}(15.6)$ & $\mathrm{H}-8$ & $\mathrm{C}-6,8,9$ \\
\hline 8 & $132.6, \mathrm{CH}^{2}-7$ & & $\mathrm{C}-6,7,9$ \\
\hline 9 & $197.5, \mathrm{CO}$ & & & \\
\hline 10 & $28.3, \mathrm{CH}_{3}$ & $2.28, \mathrm{~d}(15.6)$ & $\mathrm{C}-4,6$ \\
\hline 11 & $19.8, \mathrm{CH}_{3}$ & $1.19, \mathrm{~s}$ & $\mathrm{C}-1,2,6,13$ \\
\hline 12 & $25.0, \mathrm{CH}_{3}$ & $0.98, \mathrm{~s}$ & & $\mathrm{C}-1,2,6,12$ \\
\hline 13 & $29.3, \mathrm{CH}_{3}$ & $1.19, \mathrm{~s}$ & & \\
\hline
\end{tabular}

Table 1: NMR data for compound 2 in $\mathrm{CDCl}_{3}\left({ }^{1} \mathrm{H} 300.13,{ }^{13} \mathrm{C} 75.47 \mathrm{MHz}\right)$

\begin{tabular}{|c|c|c|c|c|}
\hline Position & $\delta_{\mathrm{C}}$, type & $\delta_{\mathrm{H}},(\mathrm{J}$ in Hz$)$ & COSY & HMBC \\
\hline 1 & $41.4, \mathrm{C}$ & & & \\
\hline $2 \alpha$ & $49.5, \mathrm{CH}_{2}$ & $2.51, \mathrm{~d}(17.0)$ & $\mathrm{H}-2 \beta$ & $\mathrm{C}-1,3,11$ \\
\hline$\beta$ & & $2.34, \mathrm{~d}(17.0)$ & $\mathrm{H}-2 \alpha$ & \\
\hline 3 & $197.0, \mathrm{CO}$ & & & \\
\hline 4 & $127.8, \mathrm{CH}$ & $5.96, \mathrm{brt}(1.0)$ & $\mathrm{H}-2 \beta, 13$ & $\mathrm{C}-2,6,13$ \\
\hline 5 & $160.4, \mathrm{C}$ & & & \\
\hline 6 & $79.3, \mathrm{C}$ & & & \\
\hline 7 & $145.0, \mathrm{CH}$ & $6.84, \mathrm{~d}(15.7)$ & $\mathrm{H}-8$ & $\mathrm{C}-5,6,9$ \\
\hline 8 & $130.3, \mathrm{CH}$ & $6.47, \mathrm{~d}(15.7)$ & $\mathrm{H}-7$ & $\mathrm{C}-6,9$ \\
\hline 9 & $197.4, \mathrm{CO}$ & & & \\
\hline 10 & $28.4, \mathrm{CH}_{3}$ & $2.31, \mathrm{~s}$ & & $\mathrm{C}-8,9$ \\
\hline 11 & $18.7, \mathrm{CH}_{3}$ & $1.88, \mathrm{~s}$ & & $\mathrm{C}-4,5,6$ \\
\hline 12 & $24.3, \mathrm{CH}_{3}$ & $1.03, \mathrm{~s}$ & & $\mathrm{C}-1,2,13$ \\
\hline 13 & $22.9, \mathrm{CH}_{3}$ & $1.11, \mathrm{~s}$ & & $\mathrm{C}-1,2,12$ \\
\hline
\end{tabular}

Table 2: NMR data for compound 3 in $\mathrm{CDCl}_{3}\left({ }^{1} \mathrm{H} 300.13,{ }^{13} \mathrm{C} 75.47 \mathrm{MHz}\right)$ 
Citation: Silva M, Vieira LMM, Almeida AP, Silva AMS, Seca AML, et al. (2013) Chemical Study and Biological Activity Evaluation of Two Azorean Macroalgae: Ulva rigida and Gelidium microdon. Oceanography 1: 102. doi:10.4172/2332-2632.1000102

\begin{tabular}{|c|c|c|c|}
\hline Position & $\delta_{\mathrm{C}}$, type & $\delta_{\mathrm{H}},(J \mathrm{in} \mathrm{Hz})$ & HMBC \\
\hline 1 & & & \\
\hline 2 & $130.2, \mathrm{C}$ & & \\
\hline 3 & $146.5, \mathrm{C}$ & & \\
\hline 4 & & & \\
\hline 5 & $138.4, \mathrm{C}$ & & $\mathrm{C}-7,13,15$ \\
\hline 6 & $128.7, \mathrm{CH}$ & $7.92, \mathrm{~s}$ & \\
\hline 7 & $138.9, \mathrm{C}$ & & $\mathrm{C}-6,12,16$ \\
\hline 8 & $144.7, \mathrm{C}$ & & $\mathrm{C}-2$ \\
\hline 9 & $125.8, \mathrm{CH}$ & $7.71, \mathrm{~s}$ & \\
\hline 10 & $141.6, \mathrm{C}$ & & $\mathrm{C}-2$ \\
\hline 11 & & $11.84, \mathrm{brs}$ & \\
\hline 12 & $150.1, \mathrm{CO}$ & & $\mathrm{C}-11,12,13$ \\
\hline 13 & & $11.68, \mathrm{brs}$ & $\mathrm{C}-9,12,13$ \\
\hline 14 & $160.7, \mathrm{CO}^{-}, 13, \mathrm{CH}$ & \\
\hline 15 & $19.6, \mathrm{CH}_{3}$ & $2.47, \mathrm{~s}$ & \\
\hline 16 & $20.2, \mathrm{CH}_{3}$ & $2.49, \mathrm{~s}$ & $\mathrm{C}$ \\
\hline
\end{tabular}

Table 3: NMR data for compound 5 in $\mathrm{CDCl}_{3}\left({ }^{1} \mathrm{H} 300.13,{ }^{13} \mathrm{C} 75.47 \mathrm{MHz}\right)$.

assess cell growth as previously described [33]. The cell cultures used were from different sources. MCF-7 and A375-C5 were obtained from the European Collection of Cell Cultures (ECACC) while NCI-H460 was provided by the NCI collection of cell lines. Briefly, compounds 1 , 2 and the crude extracts were aseptically dissolved in DMSO and stored at $-20^{\circ} \mathrm{C}$. Appropriate dilutions of the compounds and extracts were freshly prepared just prior the assay and diluted with growth medium. Final concentrations of DMSO did not interfere with the growth of cell lines. Cells growing as monolayer, were routinely maintained in RPMI-1640 medium containing $5 \% \mathrm{FBS}$, at $37^{\circ} \mathrm{C}$ in a humidified atmosphere containing $5 \% \mathrm{CO}_{2}$. For the assays, each cell line was plated at an appropriate density $\left(5 \times 10^{4}\right.$ cells $\left./ \mathrm{mL}\right)$ in 96 well-plates. Cells were incubated for $24 \mathrm{~h}$ in the humidified incubator, allowing them to stabilize and adhere. Cells were then exposed for $48 \mathrm{~h}$ at $37^{\circ} \mathrm{C}$ and $5 \% \mathrm{CO}_{2}$ to serial concentrations of compounds, extracts and the positive control, doxorubicin. Following this exposure period, cells were fixed in situ with 50\% Trichloroacetic Acid (TCA), washed with distillated water and dyed with SRB. In order to solubilize protein/SRB complexes, Tris buffer were added to each well and absorbance (Abs at $515 \mathrm{~nm}$ ) was determined in a plate reader (Biotek Synergy 2). Abs values were retrieved using Gene5software (Biotek). For each cell line a dose-response curve was obtained and the growth inhibition of 50\% $\left(\mathrm{GI}_{50}\right)$ corresponding to the concentration of compounds and extracts that inhibited $50 \%$ of the net cell growth was calculated according to the procedure adopted by the NCI.

\section{Antifungal assays}

Broth microdilution methods based on Clinical and Laboratory Standards Institute (CLSI) reference protocols M27-A3 and M38-A2 for yeasts (Candida albicans) and filamentous fungi (Aspergillus fumigatus and dermatophytes), respectively, were used to determine the MIC and MLC of the crude extracts and the isolated metabolites [34]. Candida albicans ATCC 10231, Aspergillus fumigatus ATCC 46645 and dermatophytes: Epidermophyton floccosum FF9, Microsporum canis FF1, Microsporum gypseum FF3, Trichophyton mentagrophytes FF7, and Trichophyton rubrum FF5 were used as test organisms. The yeast cell suspensions were prepared in $0.85 \% \mathrm{NaCl}$ and the transmittance of cell density adjusted to that produced by a $0.5 \mathrm{McF}$ arland standard for C. albicans. To achieve an inoculum size of $1-5 \times 10^{3} \mathrm{CFU} / \mathrm{mL}$ for C. albicans, the cell suspension was diluted with RPMI 1640. For filamentous fungi, the spore suspensions were prepared in $0.85 \%$
$\mathrm{NaCl}$ with Tween 20 and the cell density adjusted at 20-250 conidia/ square (hemocytometer) for A. fumigatus and 20-60 conidia/square for dermatophytes. To achieve an inoculum size of $0.4-5 \times 10^{4} \mathrm{CFU} / \mathrm{mL}$ for A. fumigatus and $1-3 \times 10^{3} \mathrm{CFU} / \mathrm{mL}$ for dermatophytes, the spore suspensions were diluted with RPMI 1640. The solutions of the extracts and compounds 1 and 2 were prepared in DMSO and added to the cell suspensions in order to obtain test concentrations ranging from 16 to $256 \mu \mathrm{g} / \mathrm{mL}$. In addition, reference antifungal compound, fluconazole was used as standard antifungal drug. Controls without crude extracts and isolated compounds, as well as sterility and DMSO control wells, were also included. The plates were incubated aerobically at $35^{\circ} \mathrm{C}$ $\pm 0.2^{\circ} \mathrm{C}$ for $24 \mathrm{~h} / 48 \mathrm{~h}$ in atmospheric humidity (C. albicans and $A$. fumigatus) and at $25^{\circ} \mathrm{C} \pm 0.2^{\circ} \mathrm{C}$ for 5 days in atmospheric humidity for dermatophytes. To evaluate the MLCs, $20 \mu \mathrm{L}$ samples were taken from each negative well and the first well exhibiting growth (serve as a growth control), after MIC reading, spotted onto SDA (Sabouraud Dextrose Agar) plates and incubated at $35^{\circ} \mathrm{C} \pm 0.2^{\circ} \mathrm{C} 24 \mathrm{~h} / 48 \mathrm{~h}$ (C. albicans and $A$. fumigatus) or at $25^{\circ} \mathrm{C} \pm 0.2^{\circ} \mathrm{C}$ for 7 days (dermatophytes).

\section{Antibacterial assays}

A broth microdilution method, based on CLSI reference protocol M7-A7, was used to determine the MIC and MLC of the crude extracts and the isolated metabolites [35]. Escherichia coli ATCC 25922, Pseudomonas aeruginosa ATCC 27853, Staphylococcus aureus ATCC 25923, and Methicillin Resistant Staphylococcus aureus (MRSA), clinical isolate, were used as test organisms. The cell suspensions were prepared in $0.85 \% \mathrm{NaCl}$ and the transmittance of cell density adjusted to that produced by a $0.5 \mathrm{McF}$ arland standard. To achieve an inoculum size of $10^{5} \mathrm{CFU} / \mathrm{mL}$, the cell suspensions were diluted with MHB (Muller-Hinton Broth). The stock solutions of the extracts, and compounds 1 and 2 were prepared in DMSO and further diluted in serial two-folds with MHB to final concentrations ranging from 16 to $256 \mu \mathrm{g} / \mathrm{mL}$. In addition, gentamicin was used as standard antibacterial drug and controls without crude extracts and isolated compounds, as well as sterility and DMSO control wells, were also included. The plates were incubated aerobically at $35^{\circ} \mathrm{C} \pm 0.2^{\circ} \mathrm{C}$ for $16 \mathrm{~h} / 20 \mathrm{~h}$ in atmospheric humidity. To measure the MLCs, $20 \mu \mathrm{L}$ samples were taken from each negative well and the first well exhibiting growth (serve as a growth control), after MIC reading, spotted onto MHA (Muller-Hinton Agar) plates and incubated at $35^{\circ} \mathrm{C} \pm 0.2^{\circ} \mathrm{C}$ for $24 \mathrm{~h}$.

\section{Results and Discussion}

The structures of the compounds were established mainly by $1 \mathrm{D}\left({ }^{1} \mathrm{H}\right.$ and ${ }^{13} \mathrm{C}$ NMR) and 2D (COSY, DEPT, HSQC and HMBC experiments) spectroscopic techniques as well as comparison of their NMR data with those reported in the literature.

Compound 1 was isolated as white crystals with $\mathrm{mp} 129-131^{\circ} \mathrm{C}$. The ${ }^{13} \mathrm{C}$ NMR, DEPT and HSQC spectra revealed the presence of twenty nine carbon signals which can be categorized as two quaternary $\mathrm{sp}^{2}$ $(\delta c 145.9,140.7)$, two methine $\mathrm{sp}^{2}(\delta \mathrm{c} 121.7,116.4)$, two quaternary $\mathrm{sp}^{3}(\delta \mathrm{c} 42.3,36.5)$, one oxymethine $\mathrm{sp}^{3}(\delta \mathrm{c} 71.8)$, six methine $\mathrm{sp}^{3}(\delta \mathrm{c}$ $56.7,56.0,50.1,36.1,31.9,28.6)$, ten methylene $\operatorname{sp}^{3}(\delta \mathrm{c} 42.3,39.8,37.2$, $35.9,31.9,31.6,28.2,27.9,24.3,21.1)$ and six methyl $(\delta \mathrm{c} 21.1,21.0$, $19.4,18.8,12.8,11.8)$ carbons. The HMBC correlations of $\mathrm{H}-6\left(\delta_{\mathrm{H}} 5.35\right.$, $d d, J=4.4,1.7, \delta \mathrm{c} 121.7)$ to C-4 ( $\delta \mathrm{c} 42.3), \mathrm{C}-8$ ( $\delta \mathrm{c} 31.9), \mathrm{C}-10(\delta \mathrm{c} 36.5)$ revealed the presence of a trisubstituted double bond between $\mathrm{C}-5$ and C-6. That another trisubstituted double bond was on C-24 and C-28 was corroborated by the HMBC correlations of $\mathrm{H}-28\left(\delta_{\mathrm{H}} 5.10, q, J=6.8\right.$, $\delta c 116.4)$ to $\mathrm{C}-25$ ( $\delta \mathrm{c} 28.6)$ and C-29 ( $\delta \mathrm{c} 12.8)$. The coupling constants of $\mathrm{H}-3$ suggested that the $\mathrm{C}-3$ hydroxyl group was $\beta$. The ${ }^{1} \mathrm{H}$ and ${ }^{13} \mathrm{C}$ 
chemical shift values of compound 1 were compatible with those of isofucosterol [36,37]. Isofucosterol is a common phycosterol and it has been previously reported from several macroalgae [38].

The ${ }^{13} \mathrm{C}$ NMR spectrum of compound 2 displayed thirteen carbon signals which were categorized, by DEPT and HSQC experiments (Table 1), as one carbonyl of a conjugated ketone $(\delta$ 197.5), two methine $\operatorname{sp}^{2}\left(\delta_{c} 132.6,142.4\right)$, two oxyquaternary $\mathrm{sp}^{3}\left(\delta_{c} 69.4,67.3\right)$, one quaternary $\mathrm{sp}^{3}\left(\delta_{c} 35.1\right)$, one oxymethine $\mathrm{sp}^{3}\left(\delta_{c} 64.0\right)$, two methylene $\operatorname{sp}^{3}(\delta 40.5,46.6)$ and four methyl $(\delta, 19.8,24.9,28.3,29.3)$ carbons. The COSY spectrum displayed cross peak between the olefinic protons at $\delta_{\mathrm{H}}$ $7.03 \mathrm{~d}(J=15.6)$ and $\delta_{\mathrm{H}} 6.29 \mathrm{~d}(J=15.6)$, confirming the presence of a trans double bond. That this trans double bond was part of the 3-oxobutenyl side chain which linked to C- 6 of the cyclohexanol moiety was supported by the HMBC correlations of the methyl protons signal at $\delta_{\mathrm{H}} 2.28 \mathrm{~s}\left(\delta_{\mathrm{C}} 28.3\right)$ to the carbon signals at $\delta_{\mathrm{C}} 132.6(\mathrm{C}-8), \delta_{\mathrm{C}} 142.4(\mathrm{C}-7)$ and $\delta_{\mathrm{C}} 197.5(\mathrm{C}-9)$, as well as of the proton signal at $\delta_{\mathrm{H}} 6.29 \mathrm{~d}, J=15.6$ $\left(\delta_{\mathrm{C}} 132.6\right)$ to the carbon signals at $\delta_{\mathrm{C}} 197.5(\mathrm{C}-9), \delta_{\mathrm{C}} 142.4(\mathrm{C}-7), \delta_{\mathrm{C}} 69.4$ $(\mathrm{C}-6)$. As the proton signals of the methyl groups at $\delta_{\mathrm{H}} 0.98\left(\delta_{\mathrm{C}} 25.0\right)$ and $\delta_{\mathrm{H}} 1.19 \mathrm{~s}\left(\delta_{\mathrm{C}} 29.3\right)$ gave cross peaks to the quaternary carbon signal at $\delta_{\mathrm{C}} 35.1(\mathrm{C}-1)$ as well as to the carbon signals at $\delta_{\mathrm{C}} 46.6(\mathrm{C}-2)$ and $\delta_{\mathrm{C}}$ 69.4 (C-6), they were assigned for C-12 and C-13, respectively. These correlations led to the conclusion that the structure of compound 2 should correspond to $7(E)$-3 $\beta$-hydroxy-5, 6-epoxymegastigmane. As compound 2 is levorotatory with $[\alpha]_{D}^{25}=-38.5^{\circ}$, it was identified as $7(E)$ - $3 \beta$-hydroxy- $5 \alpha, 6 \alpha$-epoxymegastigmane. The ${ }^{1} \mathrm{H}$ and ${ }^{13} \mathrm{C} \mathrm{NMR}$ data of compound 2 were compatible with those of $(3 S, 5 R, 6 S, 7 E)$ 5, 6-epoxy-3-hydroxy-7-megastigmen-9-one, previously isolated from the solanaceous plant Cestrum parqui L' Hérit [32].

Compound 3 was isolated as a mixture, as was evidenced by its ${ }^{1} \mathrm{H}$ NMR spectrum. Through the HMBC correlations, two sets of carbon signals could be discerned in the ${ }^{13} \mathrm{C}$ NMR spectrum of the mixture (Table 2). The first set of the carbon signals, belonging to compound 3, comprised of thirteen carbon signals which were identified by DEPT and HSQC as two carbonyls $\left(\delta_{C} 197.4\right.$ and $\left.\delta_{C} 197.0\right)$, one quaternary $\mathrm{sp}^{2}$ $\left(\delta_{\mathrm{C}} 160.4\right)$, three methine $\mathrm{sp}^{2}\left(\delta_{\mathrm{C}} 127.8,130.3,145.0\right)$, one oxyquaternary $\mathrm{sp}^{3}\left(\delta_{\mathrm{C}} 79.3\right)$, one quaternary $\mathrm{sp}^{3}\left(\delta_{\mathrm{C}} 41.2\right)$, one methylene $\left(\delta_{\mathrm{C}} 49.5\right)$, and four methyl $\left(\delta_{C} 18.7,22.9,24.3,28.4\right)$ carbons. Similar to compound 2 , there was a 3-oxo-butenyl side chain which linked to the cyclohexenone moiety through the oxyquaternary $\mathrm{sp}^{3}$ carbon at $\delta_{\mathrm{C}} 79.3$, as was evidenced by the HMBC correlations of the methyl proton signal at $\delta_{\mathrm{C}}$ $2.31 \mathrm{~s}\left(\mathrm{CH}_{3}-10\right)$ to $\mathrm{C}-8\left(\delta_{\mathrm{C}} 130.3\right)$ and $\mathrm{C}-9\left(\delta_{\mathrm{C}} 197.4\right)$, as well as of $\mathrm{H}-8$ signal $\left(\delta_{\mathrm{H}} 6.47, \mathrm{~d}, J=15.7 \mathrm{~Hz}\right)$ to $\mathrm{C}-9\left(\delta_{\mathrm{C}} 197.4\right)$ and $\mathrm{C}-6\left(\delta_{\mathrm{C}} 79.3\right)$. The presence of the 3,5,5-trimethyl-4-hydroxy-2-cyclohexenone moiety was confirmed by the HMBC correlations of the olefinic proton signal at $\delta_{\mathrm{H}} 5.96$, brt, $J=1.0 \mathrm{~Hz}\left(\delta_{\mathrm{C}} 127.8\right)$ to $\mathrm{CH}_{3}-11\left(\delta_{\mathrm{C}} 18.7\right), \mathrm{C}-2\left(\delta_{\mathrm{C}} 49.5\right)$, C-6 $\left(\delta_{\mathrm{C}} 79.3\right)$, as well as of the methyl proton signals at $\delta_{\mathrm{H}} 1.03 \mathrm{~s}\left(\delta_{\mathrm{H}}\right.$ $\left.24.3, \mathrm{CH}_{3}-12\right)$ and $\delta_{\mathrm{H}} 1.11 \mathrm{~s}\left(\delta_{\mathrm{H}} 22.9, \mathrm{CH}_{3}-13\right)$ to $\mathrm{C}-1\left(\delta_{\mathrm{C}} 41.2\right), \mathrm{C}-2\left(\delta_{\mathrm{C}}\right.$ $49.5)$ and $\mathrm{C}-6\left(\delta_{\mathrm{C}} 79.3\right)$. The structure of compound 3 was established as $(+)$-dehydrovomifoliol, previously isolated from several plant sources [39]. However, due to the small quantity of the mixture isolated, it was not possible to isolate 3 as a pure compound to determine its optical rotation.

Compound 5 was isolated as green amorphous powder and its molecular formula $\mathrm{C}_{12} \mathrm{H}_{10} \mathrm{~N}_{4} \mathrm{O}_{2}$ was established on the basis of the (+)-HR-ESIMS $m / z 243.0918[\mathrm{M}+\mathrm{H}]^{+}($calcd 243.0882$)$, indicating ten degrees of unsaturation. The ${ }^{13} \mathrm{C}$ NMR, DEPT and HSQC spectra (Table 3 ) revealed the presence of two amide carbonyls $\left(\delta_{C} 160.7,150.1\right)$, six quaternary $\operatorname{sp}^{2}\left(\delta_{\mathrm{C}} 130.2,138.4,138.9,141.6,144.7,146.5\right)$, two methine
$\operatorname{sp}^{2}\left(\delta_{C} 125.8,128.7\right)$ and two methyl $\left(\delta_{C} 19.6,20.2\right)$ carbons. The HMBC spectrum displayed cross peaks of the amide proton signals at $\delta_{\mathrm{H}}$ $11.7 \mathrm{~s}(\mathrm{NH}-13)$ and $\delta_{\mathrm{H}} 11.8 \mathrm{~s}(\mathrm{NH}-11)$ to the carbon signal at $\delta_{\mathrm{C}} 130.2$ $(\mathrm{C}-2)$. While the proton signal at $\delta_{\mathrm{H}} 7.92 \mathrm{~s}\left(\delta_{\mathrm{C}} 128.7\right)$ showed $\mathrm{HMBC}$ correlations to $\mathrm{C}-8\left(\delta_{\mathrm{C}} 144.7\right), \mathrm{C}-10\left(\delta_{\mathrm{C}} 141.6\right)$ and $\mathrm{CH}_{3}-15\left(\delta_{\mathrm{C}} 19.6\right)$, the proton signal at $\delta_{\mathrm{H}} 7.71 \mathrm{~s}\left(\delta_{\mathrm{C}} 125.9\right)$ showed HMBC correlations to $\mathrm{C}-5\left(\delta_{\mathrm{C}} 138.4\right), \mathrm{C}-7\left(\delta_{\mathrm{C}} 138.9\right)$ and $\mathrm{CH}_{3}-16\left(\delta_{\mathrm{C}} 20.2\right)$. Thus, the structure of compound 5 is 7,8 -dimethylalloxazine or commonly known as lumichrome. Lumichrome, a derivative of the vitamin riboflavin, has been purified and chemically identified from culture filtrates of the alga Chlamydomonas as a Quorum Sensing (QS) signal-mimic compound capable of stimulating the Pseudomonas aeruginosa LasR QS receptor [40]. Bacteria, plants, and algae commonly secrete riboflavin or lumichrome, raising the possibility that these compounds could serve as either QS signals or as interkingdom signal mimics capable of manipulating QS in bacteria with a LasR-like receptor [40].

The effect of the extracts of $U$. rigida and G. microdon (before and after removal of the chlorophylls), isofucosterol (1) and $7(E)$ $3 \beta$-hydroxy-5a, 6a-epoxymegastigmane (2) were evaluated for their capacity to inhibit in vitro growth of three tumor cell lines: MCF-7, NCI-H460 and A375-C5. The results showed that the crude extracts were moderately active against the three cell lines; however, isofucosterol (1) was found to be less active than the crude extract of $U$. rigida, while $7(E)-3 \beta$-hydroxy-5a,6a-epoxymegastigmane (2) was inactive (Table 4).

The crude methanol extracts of $U$. rigida and G. microdon (before and after removal of the chlorophylls) were also evaluated for their antifungal activity against $C$. albicans, $A$. fumigatus, and dermatophytes E. floccosum, M. canis, M. gypseum, T. mentagrophytes, and T. rubrum. The results showed that removal of the chlorophylls caused an increase in antifungal activity of $U$. rigida against T. rubrum, T. mentagrophytes, $M$. canis, and E. floccosum. Whereas T. rubrum showed higher susceptibility, M. gypseum showed more resistance (MIC higher than $256 \mu \mathrm{g} / \mathrm{mL}$ ). Removal of the chlorophylls also caused an increase in the activity of G. microdon crude extract against T. rubrum and $E$. floccosum. It was found that $M$. canis showed more susceptibility while T. mentagrophytes and $M$. gypseum showed higher resistance. Interestingly, both isofucosterol (1) and $7(E)-3 \beta$-hydroxy-5a,6aepoxymegastigmane (2) were inactive against all the tested organisms (Table 5).

\begin{tabular}{|l|c|c|c|}
\hline Extract/Compounds & \multicolumn{3}{|c|}{ Cell lines / GI ${ }_{50}(\mu \mathrm{g} / \mathrm{ml})$} \\
\hline $\begin{array}{l}\text { U. rigida (before removal of } \\
\text { chlorophylls) }\end{array}$ & $44.5 \pm 18.4$ & $49.1 \pm 14.0$ & $40.8 \pm 10.2$ \\
\hline $\begin{array}{l}\text { U. rigida (after removal of chlorophylls) } \\
\text { G. }\end{array}$ & $43.0 \pm 10.3$ & $41.9 \pm 12.1$ & $44.5 \pm 7.6$ \\
\hline $\begin{array}{l}\text { G. microdon (before removal of } \\
\text { chlorophylls) }\end{array}$ & $75.9 \pm 16.1$ & $70.6 \pm 20.1$ & $36.3 \pm 8.0$ \\
\hline $\begin{array}{l}\text { G. microdon (after removal of } \\
\text { chlorophylls) }\end{array}$ & $63.1 \pm 14.1$ & $64.9 \pm 16.6$ & $62.6 \pm 15.9$ \\
\hline & \multicolumn{3}{|c|}{ Cell lines / GI ${ }_{50}(\mu \mathrm{M})$} \\
\hline & MCF-7 & $\mathrm{NCl}-\mathrm{H} 460$ & $\mathrm{~A} 375-\mathrm{C} 5$ \\
\hline 1 & $122.2 \pm 17.9$ & $128.4 \pm 32.4$ & $119.2 \pm 28.9$ \\
\hline 2 & $\geq 200$ & $\geq 200$ & $\geq 200$ \\
\hline
\end{tabular}

${ }^{*}$ Results are given as the lowest concentrations causing $50 \%$ of cell growth inhibition $\left(\mathrm{GI}_{50}\right)$ after a continuous exposure to the compounds for 48 hours and are expressed as means \pm SEM of three independent experiments performed in triplicate. Doxorubicin was used as positive control, $\mathrm{GI}_{50}: \mathrm{MCF}-7=60.3 \pm 1.2 \mathrm{nM}$ $\mathrm{NCl}-\mathrm{H} 460=19.6 \pm 1.9 \mathrm{nM} ; \mathrm{A} 375-\mathrm{C} 5=130 \pm 25.2 \mathrm{nM}$.

Table 4: Growth inhibitory effect of crude methanol extracts of $U$. rigida and $G$. microdon, compounds 1 and 2 , in different cell lines*. 
Citation: Silva M, Vieira LMM, Almeida AP, Silva AMS, Seca AML, et al. (2013) Chemical Study and Biological Activity Evaluation of Two Azorean Macroalgae: Ulva rigida and Gelidium microdon. Oceanography 1: 102. doi:10.4172/2332-2632.1000102

Page 6 of 7

\begin{tabular}{|c|c|c|c|c|c|c|c|c|}
\hline \multirow[t]{2}{*}{ Extract/ Compound } & \multicolumn{8}{|c|}{ Fungi / $\mu \mathrm{g} / \mathrm{mL}$} \\
\hline & & C. albicans & A. fumigatus & T. rubrum & T. mentagrophytes & E. floccosum & M. canis & M. gypseum \\
\hline \multirow[t]{2}{*}{$U$. rigida (before removal of chlorophylls) } & MIC & $>256$ & $>256$ & $>256$ & $>256$ & $>256$ & $>256$ & $>256$ \\
\hline & MLC & $>256$ & $>256$ & $>256$ & $>256$ & $>256$ & $>256$ & $>256$ \\
\hline \multirow[t]{2}{*}{$U$. rigida (after removal of chlorophylls) } & MIC & $>256$ & $>256$ & $64-128$ & $128-256$ & $128-256$ & 128 & $>256$ \\
\hline & MLC & $>256$ & $>256$ & 128 & $128-256$ & $\geq 256$ & 128 & $>256$ \\
\hline \multirow[t]{2}{*}{ G. microdon (before removal of chlorophylls) } & MIC & $>256$ & $>256$ & $\geq 256$ & $>256$ & $>256$ & $>256$ & $>256$ \\
\hline & MLC & $>256$ & $>256$ & $\geq 256$ & $>256$ & $>256$ & $>256$ & $>256$ \\
\hline \multirow[t]{2}{*}{ G. microdon (after removal of chlorophylls) } & MIC & $>256$ & $>256$ & $64-128$ & 256 & $64-256$ & 64 & $>256$ \\
\hline & MLC & $>256$ & $>256$ & $64-128$ & $\geq 256$ & $128-256$ & 64 & $>256$ \\
\hline \multirow[t]{2}{*}{1} & MIC & $>256$ & $>256$ & $>256$ & $>256$ & $>256$ & $>256$ & $>256$ \\
\hline & MLC & $>256$ & $>256$ & $>256$ & $>256$ & $>256$ & $>256$ & $>256$ \\
\hline \multirow[t]{2}{*}{2} & MIC & $>256$ & $>256$ & $>256$ & $>256$ & $>256$ & $>256$ & $>256$ \\
\hline & MLC & $>256$ & $>256$ & $>256$ & $>256$ & $>256$ & $>256$ & $>256$ \\
\hline
\end{tabular}

*The MIC values were determined as the lowest concentration of the crude extract or compound revealed $100 \%$ growth inhibition. The MLC values were determined as the lowest concentration of the crude extract or compound causing fungal death. All experiments were performed in duplicate and repeated at least three times. Quality control was performed by testing the inhibitory activity of fluconazole with the reference strain C. parapsilosis ATCC 90018 (CLSI standard for MIC $=0.5-2 \mu \mathrm{g} / \mathrm{mL}$ )

Table 5: Antifungal effect of the crude methanol extracts of $U$. rigida and G. microdon, compounds 1 and 2 , in different selected fungi*

\begin{tabular}{|c|c|c|c|c|c|}
\hline \multirow[t]{2}{*}{ Extract/ Compound } & \multicolumn{5}{|c|}{ Bacteria / $\mathrm{\mu g} / \mathrm{mL}$} \\
\hline & & E. coli & $P$. aeruginosa & S. aureus & MRSA \\
\hline \multirow[t]{2}{*}{ U. rigida (before removal of chlorophylls) } & MIC & $>256$ & $>256$ & $>256$ & $>256$ \\
\hline & MLC & $>256$ & $>256$ & $>256$ & $>256$ \\
\hline \multirow[t]{2}{*}{$U$. rigida (after removal of chlorophylls) } & MIC & $>256$ & $>256$ & $>256$ & 128 \\
\hline & MLC & $>256$ & $>256$ & $>256$ & $>256$ \\
\hline \multirow[t]{2}{*}{ G. microdon (before removal of chlorophylls) } & MIC & $>256$ & $>256$ & $>256$ & $>256$ \\
\hline & MLC & $>256$ & $>256$ & $>256$ & $>256$ \\
\hline \multirow[t]{2}{*}{ G. microdon (after removal of chlorophylls) } & MIC & $>256$ & $>256$ & 64 & $32-64$ \\
\hline & MLC & $>256$ & $>256$ & $>256$ & $64-128$ \\
\hline \multirow[t]{2}{*}{1} & MIC & $>256$ & $>256$ & $>256$ & $>256$ \\
\hline & MLC & $>256$ & $>256$ & $>256$ & $>256$ \\
\hline \multirow[t]{2}{*}{2} & MIC & $>256$ & $>256$ & $>256$ & $>256$ \\
\hline & MLC & $>256$ & $>256$ & $>256$ & $>256$ \\
\hline
\end{tabular}

*The MIC values were determined as the lowest concentration of the crude extract or compound revealed $100 \%$ growth inhibition. The MLC values were determined as the lowest concentration of the crude extract or compound causing bacterial death. All experiments were performed in duplicate and repeated at least three times. Quality control was performed by testing the inhibitory activity of gentamicin against $E$. coli ATCC 25923 (CLSI standard for MIC $=0.25-1 \mu \mathrm{g} / \mathrm{mL})$.

Table 6: Antibacterial effect of the crude methanol extracts of $U$. rigida and G. microdon, compounds 1 and 2 , in different selected bacteria*

The extracts of $U$. rigida and G. microdon (before and after removal of the chlorophylls) were evaluated for their activity against $E$. coli, $P$. aeruginosa, S. aureus, and MRSA. The results (Table 6) showed that the crude methanol extract of $U$. rigida (before and after removal of the chlorophylls) did not show any antibacterial activity against $E$. coli, $P$. aeruginosa and $S$. aureus, however removal of the chlorophylls caused a weak activity against MRSA. Similarly, the crude methanol extract of G. microdon did not show any activity against the test bacteria; however removal of the chlorophylls showed a weak activity against $S$. aureus and that sensitivity increases against MRSA. Interestingly, neither isofucosterol (1) nor 7(E)-3 $\beta$-hydroxy-5a,6a-epoxymegastigmane (2) showed activity against all the strains of tested organisms (Table 6).

\section{Acknowledgments}

This work was financially supported by the project "Bioactive products in marine algae of Azores (PTDC/MAR/100482/2008)", through Fundação para a Ciência e a Tecnologia (FCT), COMPETE, QREN, FEDER, MCTES, and partially supported by CEQUIMED-PEst-OE/SAU/UI4040/2011, Project "PEst-C/MAR/ LA0015/2011 and QOPNA-PEst-C/QUI/UI0062/2011. Madalena Silva thanks FCT for the young researcher scholarship under the PTDC/MAR/100482/2008 project.

\section{References}

1. Kijjoa A, Sawangwong P (2004) Drugs and Cosmetics from the Sea. Mar Drugs 2: $73-82$

2. Newman DJ, Cragg GM (2004) Marine Natural Products and Related
Compounds in Clinical and Advanced Preclinical Trials. J Nat Prod 67: 12161238.

3. Simmons TL, Andrianasolo E, McPhail K, Flatt P, Gerwick WH (2005) Marine natural products as anticancer drugs. Mol Cancer Ther 4: 333-42.

4. Folmer F, Jaspars M, Dicato M, Diederich M (2008) Marine natural products as targeted modulators of the transcription factor NF-kappaB. Biochem Pharmacol 75: 603-617.

5. Boopathy NS, Kathiresan K (2010) Anticancer Drugs from Marine Flora: An overview. J Oncology 1-18.

6. Wijesekara I, Pangestuti R, Kim SK (2011) Biological activities and potential health benefits of sulfated polysaccharides derived from marine algae. Carbohyd Polym 84: 14-21.

7. León-Cisneros K, Tittley I, Terra MR, Nogueira EM, Neto Al (2012) The marine algal (seaweed) flora of the Azores: 4, further additions. Life Mar Sci 29: 25-32.

8. Neto Al (2005) Observations on the biology and ecology of selected macroalgae from the littoral of São Miguel (Azores). Bot Mar 43: 483-498.

9. Neto $\mathrm{Al}$ (2001) Macroalgal species diversity and biomass of subtidal communities of São Miguel (Azores). Helgoland Mar Res 55: 101-111.

10. Wallenstein FM, Couto RP, Amaral AS, Wilkinson M, Neto Al, et al. (2009) Baseline metal concentrations in marine algae from São Miguel (Azores) under different ecological conditions - Urban proximity and shallow water hydrothermal activity. Mar Pollut Bull 58: 424-455.

11. Dhargalkar VK, Verlecar XN (2009) Southern Ocean seaweeds: A resource for exploration in food and drugs. Aquacultures 287: 229-242. 
Citation: Silva M, Vieira LMM, Almeida AP, Silva AMS, Seca AML, et al. (2013) Chemical Study and Biological Activity Evaluation of Two Azorean Macroalgae: Ulva rigida and Gelidium microdon. Oceanography 1: 102. doi:10.4172/2332-2632.1000102

12. Paiva LS, Patarra RF, Neto Al, Lima EMC, Baptista JAB (2011) Antioxidant activity of macroalgae from the Azores. Life Mar Sci 29: 1-6.

13. Shalaby EA (2011) Algae as promising organisms for environment and health. Plant Signal Behav 6: 1338-1350.

14. Gupta S, Abu-Ghannam N (2011) Bioactive potential and possible health effects of edible brown seaweeds. Trends Food Sci Tech 22: 315-326.

15. Khanavi M, Gheidarloo R, Sadati N, Ardekani MRS, Nabavi SMB, et al. (2012) Cytotoxicity of fucosterol containing fraction of marine algae against breast and colon carcinoma cell line. Pharmacogn Mag 8: 60-64.

16. Medeiros J, Macedo M, Constância J, LoDuca J, Cunningham G, et al. (1999) Potential anticancer activity from plants and marine organisms collected in the Azores. Açoreana 9: 55-61.

17. Neto Al, Tittley I, Raposeiro P (2005) Flora Marinha do Litoral dos Açores [Rocky Shore Marine Flora of the Azores]. Secretaria Regional do Ambiente e do Mar, Açores.

18. Toskas G, Hund R-D, Laourine E, Cherif C, Smyrniotopoulos V, et al. (2011) Nanofibers based on polysaccharides from the green seaweed Ulva rigida. Carbohyd Polym 84: 1093-1102.

19. Kerr RG, Baker BJ (1991) Marine Sterols. Nat Prod Rep 8: 465-497.

20. Renn DW (1984) Agar and agarose: indispensable partners in biotechnology. Ind Eng Chem Prod Res Dev 23: 17-21.

21. Flodin C, Whitfield FB (1999) 4-Hydroxybenzoic acid: a likely precursor of 2,4,6-tribromophenol in Ulva lactuca. Phytochemistry 51: 249-255.

22. Silva VM, Lopes WA, Andrade JB, Veloso MCC, Santos GV, et al. (2007) Bromofenóis simples relacionados ao "Flavor" de organismos marinhos. Quím Nova 30: 629-635

23. Chakraborty K, Lipton AP, Raj RP, Viajayan KK (2010.1) Antibacterial labdane diterpenoids of Ulva fasciata Delile from southwestern coast of the Indian Peninsula. Food Chem 119: 1399-1408.

24. Chakraborty K, Lipton AP, Paulraj R, Chakraborty RD (2010.2) Guaiane sesquiterpenes from seaweed Ulva fasciata Delile and their antibacterial properties. Eur J Med Chem 45: 2237-2244.

25. Chakraborty K, Paulraj R (2010) Sesquiterpenoids with free radical scavenging properties from marine macroalga Ulva fasciata Delile. Food Chem 122: 31-41.

26. Kim KM, Hwang IK, Park JK, Boo SM (2011) A new Agarophyte species Gelidium Eucorneum SP. Nov. (Gelidiales, Rhodophyta) based on molecular and morphological data. J Phycol 47: 904-910.

27. Aazizi MA, Assef GM, Faure R (1989) Gelidene, a New Polyhalogenated

Citation: Silva M, Vieira LMM, Almeida AP, Silva AMS, Seca AML, et al. (2013) Chemical Study and Biological Activity Evaluation of Two Azorean Macroalgae: Ulva rigida and Gelidium microdon. Oceanography 1: 102. doi:10.4172/2332 2632.1000102 monocyclic monoterpene from red marine alga Gelidium sesquipedale. J Nat Prod 52: 829-831.

28. Gerwick WH (1993) Carbocyclic Oxylipins of Marine Origin. Chem Rev 93 1807-1823.

29. Kijjoa A, Bessa J, Pinto MMM, Anantachoke C, Silva AMS, et al. (2002) Polyoxygenated cyclohexene derivatives from Ellipeiopsis cherevensis. Phytochemistry 59: 543-549.

30. Kovganko NV, Kashkan ZN, Borisov EV (2000) ${ }^{13} \mathrm{C}$ NMR Spectra of Functionally Substituted $3 \beta$-Chloroderivatives of Cholesterol and $\beta$-Sitosterol. Chem Nat Compd 36: 595-598.

31. Rosa S, Giulio A, Tommonaro G (1997) Triterpenoids and Sterol Glucoside from cell cultures of Lycopersion esculentum. Phytochemistry 44: 861-864.

32. D'Abrosca B, DellaGreca M, Fiorentino A, Monaco P, Oriano P, et al. (2004) Structure elucidation and phytotoxicity of $\mathrm{C} 13$ nor-isoprenoids from Cestrum parqui. Phytochemistry 65: 497-505

33. Almeida AP, Dethoup T, Singburaudom N, Lima, R, Vasconcelos MH, et al. (2010) The in vitro anticancer activity of the crude extract of the spongeassociated fungus Eurotium cristatum and its secondary metabolites. J Nat Pharm 1: 25-29.

34. Pinto E, Afonso C, Duarte S, Vale-Silva L, Costa E, et al. (2011) Antifungal cctivity of xanthones: evaluation of their effect on ergosterol biosynthesis by high-performance liquid chromatography. Chem Biol Drug Des 77: 212-222.

35. Lopes G, Sousa C, Silva LR, Pinto E, Andrade PB, et al. (2012) Can Phlorotannins Purified Extracts Constitute a Novel Pharmacological Alternative for Microbial Infections with Associated Inflammatory Conditions? PLoS one 7: e31145.

36. Seo S, Uomori A, Yoshimura Y, Seto H, Ebizuka Y, et al. (1990) Biosynthesis of isofucosterol from $\left[2-{ }^{13} \mathrm{C}^{2} \mathrm{H}_{3}\right]$ acetate and $\left[1,2-{ }^{13} \mathrm{C}_{2}\right]$ acetate in iissue cultures of Physalis peruviana - the Stereochemistry of the hydride shift C-24 to C-25. J Chem Soc, Perkin Transactions 1: 105-109.

37. Kodai T, Umebayashi K, Nakatani T, Ishiyama K, Noda N (2007) Composition of royal Jelly II. Organic acid glycosides and sterols of royal jelly of honeybess (Apis mellifera). Chem Pharm Bull 55: 1528-1531.

38. Mahendran M, Sirisena DM (1980) Sterols of some Sri Lankan Marine Algae. J Natl Sci Council Sri Lanka 8: 69-74.

39. Ren Y, Shen L, Zhang D-W, Dai S-J (2009) Two new sesquiterpenoids from Solanum lyratum with cytotoxic activities. Chem Pharm Bull 57: 408-410.

40. Rajamani S, Bauer WD, Robinson JB, Farrow JM 3rd, Pesci EC, et al. (2008) The vitamin riboflavin and its derivative lumichrome activate the LasR bacterial quorum-sensing receptor. Mol Plant Microbe Interact 21: 1184-1192.
Submit your next manuscript and get advantages of OMICS Group submissions

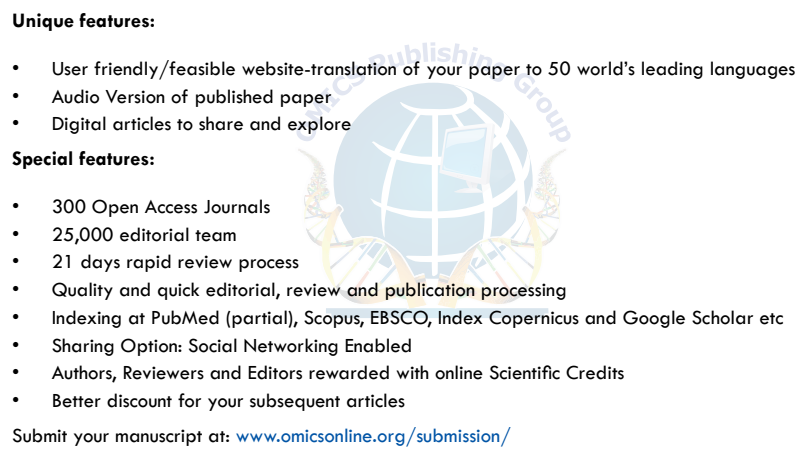

